\title{
Eksistensi dan Perkembangan ISIS: Dari Irak Hingga Indonesia
}

\author{
Najamuddin Khairur Rijal \\ Prodi Hubungan Internasional, Universitas Muhammadiyah Malang \\ Email: nkhairurrijal@gmail.com
}

\begin{abstract}
Abstrak
Tulisan ini mengkaji mengenai bagaimana perkembangan Islamic State of Iraq and Syria (ISIS) dari gerakan lokal di Irak menjadi gerakan transnasional hingga menyebar ke Indonesia. Uraian difokuskan pada sejarah perkembangan ISIS dari waktu ke waktu hingga bersentuhan dengan kelompok revivalisme Islam di Indonesia. Cita-cita ISIS adalah untuk mendirikan kekhalifahan Islam di Irak dan Suriah. Dalam upaya mewujudkan tujuannya, ISIS menyebarkan ideologinya melalui beragam propaganda untuk menarik simpatisan dari berbagai negara. Dalam konteks Indonesia, masuknya paham ISIS tidak terlepas dari persentuhannya dengan kelompok yang memiliki cita-cita revivalisme Islam yang sebelumnya telah lama hadir di Indonesia. Perkembangan awal jaringan dan simpatisan ISIS di Indonesia ditandai dengan beredarnya video di Youtube berjudul "Join the Ranks" yang selanjutnya direspons oleh pemerintah dengan pelarangan ISIS baik secara formal maupun informal karena ideologi ISIS dipandang bertentangan dengan Pancasila dan kondisi keberagaman di Indonesia.
\end{abstract}

Kata Kunci: isis, indonesia, revivalisme islam, ideologi, iraq

\begin{abstract}
This article examines the development of the Islamic State of Iraq and Syria (ISIS) as the local movement in Iraq into a transnational movement and its reach in Indonesia. The explanation focuses on the historical development of ISIS overtime and its contact with Islamic revivalism in Indonesia. ISIS spreads its ideology through various propaganda to attract followers from many countries to accomplish its aspiration in establishing an Islamic caliphate in Iraq and Syria. In the Indonesian context, the inclusion of ISIS is not be separated from its contact with the Islamic revivalism groups present in Indonesia for a long time. Early development of the network and ISIS sympathizers in Indonesia was marked by the release of a video on Youtube titled "Join the Ranks", hereinafter the government responded by banning ISIS either formally or informally due to the ideological incompatibility of ISIS with Pancasila and the condition of diversity in Indonesia.
\end{abstract}

Keywords: isis, indonesia, islamic revivalism, ideology, iraq

\section{Pendahuluan}

Islamic State of Iraq dan Syria $(\text { ISIS })^{1}$ menjadi perhatian masyarakat

\footnotetext{
${ }^{1}$ Dalam bahasa Arab, ISIS disebut Ad-daulah Al-Islamiyah fil Iraq wa As-Syam. Syam merupakan istilah Arab klasik untuk Damaskus (Suriah/Syria). Namun, Syam tidak hanya mencakup Suriah tetapi juga Israel, Yordania, Lebanon, dan wilayah Palestina, dan bahkan bagian tenggara Turki. Oleh pakar Barat, daerah tersebut disebut sebagai The Levant. Karena itu, beberapa pihak dan media Barat menggunakan nama Islamic State of Iraq and the Levant (ISIL) atau Islamic State of Iraq and al-Sham. Lebih lanjut, sejak 29 Juni 2014 ISIS menamakan dirinya sebagai Islamic State (IS). Sekalipun saat ini bernama IS, dalam tulisan ini tetap digunakan istilah ISIS yang merujuk pada
}

internasional karena eksistensinya menimbulkan ancaman bagi perdamaian dan keamanan dunia melalui berbagai tindakan radikal yang dilakukannya. Citacita ISIS adalah mendirikan Negara Islam di Irak dan Syria (Suriah). Untuk mencapai tujuan tersebut, salah satu upaya yang

Islamic State of Iraq and Syria, karena singkatan tersebut lebih familiar di masyarakat internasional serta media-media mainstream umumnya masih menggunakan kata ISIS daripada IS. Dalam konteks Indonesia, istilah ISIS juga lebih dikenal dibanding IS atau beberapa pihak menerjemahkan menjadi Negara Islam Irak dan Suriah (NIIS). 
dilakukan adalah menyebarkan propaganda untuk mengajak seluruh umat Muslim dunia melakukan jihad dan membantu perjuangan mereka dalam mendirikan Negara Islam.

Propaganda ISIS dilancarkan melalui berbagai macam instrumen media sosial. Melalui propaganda tersebut ISIS mampu menarik simpati umat Islam dari berbagai negara untuk melakukan jihad sehingga ISIS bukan sekedar gerakan lokal di Irak dan Suriah, namun telah menjadi gerakan transnasional. Perkembangan ISIS menjadi gerakan transnasional tidak terlepas dari kemampuannya menggunakan teknologi informasi dan komunikasi via internet dengan efektif. $^{2}$ Hal itu menunjukkan bahwa fitur-fitur globalisasi, selain sebagai penyebab, sekaligus juga menjadi instrumen atau fasilitas bagi penyemaian gerakan-gerakan perlawanan berbasis agama. Disebut sebagai penyebab, karena kemunculan radikalisme dan ekstremisme atas dasar agama acap kali disebut sebagai respons terhadap patologi globalisasi. ${ }^{3}$

Akibat patologi tersebut, globalisasi kemudian melahirkan pihak-

\footnotetext{
2 J. M. Berger, 2014, "How ISIS Games Twitter," [online] http://www.theatlantic.com/international/archiv e/2014/06/isis-iraq-twitter-social-mediastrategy/372856/ (diakses pada 04/10/2014).

${ }^{3}$ Globalisasi dinilai melahirkan patologi, baik dalam konteks ekonomi, politik, maupun sosialbudaya. Baca Syaiful Arif, Deradikalisasi Islam: Paradigma dan Strategi Islam Kultural (Depok: Penerbit Koekoesan, 2010), hal. 14.
}

pihak yang resisten, salah satu bentuknya berupa radikalisme dan ekstremisme berdasar agama. ${ }^{4}$ Paralelisme globalisasi sebagai penyebab sekaligus instrumen itulah yang berkontribusi bagi eksistensi ISIS. Selain memanfaatkan fitur globalisasi berupa kemajuan teknologi untuk "mengundang" perjuangan jihad, fitur globalisasi itu pula yang menyebarkan ideologi ISIS ke berbagai negara sehingga dapat disebut sebagai gerakan transnasional, sekaligus sebagai ancaman global.

Pandangan lain mengatakan bahwa kemunculan ISIS tidak terlepas dari kontribusi Amerika Serikat (AS). ${ }^{5}$ Menurut

\footnotetext{
${ }^{4}$ Globalisasi dinilai cenderung meminggirkan aspirasi keagamaan dan menjadikan masyarakat tercerabut dari akar-akar identitasnya, kemudian menyisakan ruang kosong yang diisi dengan munculnya fundamentalisme dan ekstremisme yang acap kali radikal. Lihat antara lain Samuel P. Huntington, Benturan Antar Peradaban dan Masa Depan Politik Dunia, Edisi Kedelapan (Yogyakarta: Penerbit Qalam, 2004); Seal L. Yom, "Islam and Globalization: Secularism, Religion, and Radicalism," International Politics and Society 4/2002; James Petras dan Henry Veltmeyer, Globalization Unmasked: Imperialisme the 21th Century (London: Zed Books, 2001); Benjamin R. Barber, Jihad vs. McWorld: How Globalism and Tribalism are Reshaping the World (New York: Ballatine Books, 1995).

${ }^{5}$ Pandangan mengenai kemunculan ISIS yang tidak terlepas dari peran AS, seolah dipertegas oleh pernyataan mantan Menteri Luar Negeri AS Hillary Clinton dalam buku memoarnya berjudul Hard Choice, bahwa ISIS dibentuk oleh pemerintah AS bersama dan negara-negara Barat sekutunya untuk memecah belah Timur Tengah dan menjadikan kawasan itu senantiasa bergejolak. Lihat Peter Weber, "America Created the Islamic State of Iraq and Syria? Meet the ISIS "Truthers'," The Week, 2 September 2014, [online]
} 
Chenghu, ISIS justru menjadi instrument of terror yang didesain oleh AS untuk memperoleh kepentingan politik dan ekonomi di kawasan Timur Tengah. Menurut pandangan ini, invasi ke Irak melahirkan kelompok perlawanan Sunni terhadap Syiah, yang kemudian disokong oleh AS. Dengan demikian, AS berada di belakang ISIS dan ISIS menjadi momentum baru bagi AS untuk meneguhkan pengaruhnya di kawasan Timur Tengah. ${ }^{6}$

Namun demikian, terlepas dari perdebatan tentang kemunculan ISIS, jaringan dan simpatisan ISIS tersebar ke berbagai negara, termasuk di Indonesia. Tulisan ini selanjutnya mengkaji mengenai bagaimana perkembangan ISIS mulai dari cikal bakalnya di Irak hingga menunjukkan eksistensinya di Indonesia.

\section{Sejarah dan Perkembangan ISIS}

\begin{tabular}{crr}
\multicolumn{2}{c}{ Eksistensi ISIS } & seolah \\
membenarkan analisis dan & prediksi
\end{tabular}

http://theweek.com/articles/444103/americacreated-islamic-state-iraq-syria-meet-isistruthers (diakses pada 18/03/2015).

${ }^{6}$ Baca antara lain, Garikai Chengu, "War on Terror is Terrorism: How the US Helped Create Al Qaeda and ISIS," Counter Punch, Weekend Edition September 19-21, 2014, [online] http://www.counterpunch.org/2014/09/19/howthe-us-helped-create-al-qaeda-and-isis/ (diakses pada 06/03/2015); Aidan Cron, "ISIS: Born in the US," [online] http://ehschronicle.com/2015/02/isis-born-inthe-usa/ (diakses pada 06/03/2015); Marwan Bishara, "ISIL, CIA, Mossad, Quds Force, etc," Al Jazeera, 26 Februari 2015, [online] http://www.aljazeera.com/indepth/opinion/2015 /02/daesh-cia-mossad-quds-force-

150226052024592.html (diakses pada

Chandler dan Gunaratna bahwa pasca Nine Eleven (911) terjadi perkembangan dalam landscape terorisme global. ${ }^{7}$ Menurutnya, terdapat tiga perkembangan penting dalam dinamika politik dan keamanan global pasca peristiwa 911. Pertama, transformasi al-Qaida. Kedua, Irak menjadi "land of jihad'. Ketiga, dukungan masyarakat Muslim di berbagai negara, atas narasi "kebencian" terhadap Amerika Serikat (AS) dan dominasi Barat atas masyarakat Islam. Chandler dan Gunaratna menulis,

Since $9 / 11$ there have been a number of very profound developments in the landscape of global terrorism. First, al-Qaida has transformed from a group into a movement ... Western law enforcement and intelligence agencies are focusing on al-Qaida, but the threat has grown much larger. It is far more widespread. Second, the violent Islamists have declared Iraq the new 'land of jihad'. The groups in Iraq have built robust support and operational cells in the Levant and beyond . . . Third, Muslims worldwide, including moderate Muslims, are angered by the US invasion of Iraq. They see no justification for it. Many Islamist groups are aggressively harnessing the resentment among the Muslims

\footnotetext{
7 Michael Chandler dan Rohan Gunaratna, Countering Terrorism: Can We Meet the Threat of Global Violence? (London: Reaktion Books, 2007), hal. 16.
} 
including those living in the migrant communities and diasporas of the West. These extremist groups are calling upon Muslims in North America, Europe and Australasia to provide recruits and other support. In particular, after the US invasion of Iraq, Islamist groups have found a significant amount of support to continue the fight against the USA, its allies and friends. ${ }^{8}$

Kutipan di atas sejalan untuk melihat bagaimana kemunculan dan eksistensi ISIS sebagai ancaman global. Sebagaimana diuraikan lebih lanjut, ISIS dipandang merupakan transformasi alQaida dalam bentuk yang lebih radikal. ${ }^{9}$ Selain itu, ISIS menjadikan Irak dan Suriah (the Levant) sebagai pusat (the land of jihad) dari Negara Islam yang didirikan. Narasi jihad yang dipropagandakan ISIS mengajak diaspora Muslim di berbagai belahan dunia untuk mendukung perjuangan mereka dan bahkan melakukan jihad ke Irak dan Suriah. Dalam perjalanannya kemudian, ISIS tidak lagi sekadar sebagai gerakan di Irak dan Suriah, namun ideologinya telah menyebar ke berbagai negara melalui propaganda menggunakan fitur-fitur teknologi informasi dan komunikasi.

\footnotetext{
${ }^{8}$ Ibid.

${ }^{9}$ Lihat Brian Michael Jenkins, "Brothers Killing Brothers," Perspective RAND Corporation, 2014; 2-13.
}

ISIS merupakan gerakan atau kelompok ekstremis Muslim yang dibentuk pada 9 April 2013 di bawah pimpinan Abu Bakar al-Baghdadi. Cita-citanya adalah untuk mendirikan negara Islam dan menegakkan kekhilafahan Islam di Irak dan Suriah. Kalla dalam tulisannya di Harian Kompas menyebut bahwa kemunculan ISIS pada dasarnya hampir sama dengan lahirnya al-Qaida. ${ }^{10}$ Cikal bakal al-Qaida bermula dari mujahidin pembebasan Afghanistan dari pengaruh komunis serta pendudukan Rusia (Uni Soviet) pada dekade 1990-an. Saat itu, Barat (AS) memberikan dukungan senjata dan latihan militer kepada para mujahidin. Namun, pasca Perang Dingin, mujahidin berubah menjadi suatu ideologi perlawanan, terutama karena Barat tampil dengan hegemoninya atas dunia Islam sehingga memunculkan perlawanan dari pihak kelompok Islam.

Kemunculan ISIS tidak dapat dilepaskan dari pergolakan negara-negara Arab selama Arab Spring. ${ }^{11}$ Bermula dari Revolusi Tunisia 18 Desember 2010 dan Mesir 25 Januari 2011, berlanjut hingga ke Suriah. Jika di Tunisia dan Mesir gerakan rakyat berhasil melengserkan Zine alAbidine Ben Ali serta Hosni Mubarak,

\footnotetext{
${ }^{10}$ Jusuf Kalla, "NIIS dan Janji Surga," Kompas, 24 April 2015, hal. 6. Tulisan tersebut disadur dari pidato pembukaan seminar internasional tentang Perkembangan NIIS di Indonesia dan Penanggulangannya pada 23 Maret 2015.

${ }^{11}$ Ibid.
} 
maka Bashar al-Assad di Suriah tidak berhasil dilengserkan. Akibatnya, banyak pihak memberikan bantuan materiil dan persenjataan serta mengirim relawan untuk membantu kelompok oposisi melengserkan rezim Assad. Perang saudara yang terjadi di Suriah selanjutnya menjadi lahan bagi penyemaian ideologi ISIS. Karena itu, menurut Misrawi, musim semi politik yang berlangsung di dunia Arab bukan hanya musim semi Arab (al-rabi' al- 'araby) atau Arab Spring, tetapi juga musim semi kaum Islamis (al-rabi' al-islamiyyun). Sebab, selain memberi ruang bagi transformasi demokrasi, juga menimbulkan munculnya arus balik tentang lahirnya demokrasi versi kelompok Islam tertentu. ${ }^{12}$

Lebih lanjut, kemunculan ISIS di Irak tidak terlepas dari kejatuhan rezim Saddam Hussein oleh invasi AS. Lengsernya Saddam mengakibatkan hancurnya seluruh infrastruktur militer, ekonomi, politik, dan pemerintahan di Irak. Efek sampingnya kemudian adalah memudahkan munculnya berbagai gerakan destruktif, termasuk gerakan bersenjata seperti ISIS. ${ }^{13}$ Hal itu kemudian dapat dianalogikan bahwa ideologi seperti virus, akan menyerang tubuh manusia saat daya tahannya lemah. Dalam konteks negara,

12 Zuhairi Misrawi, "Dialektika Islamisme, Khilafah, dan Syariat", dalam Komaruddin Hidayat (ed.), Kontroversi Khilafah: Islam, Negara, dan Pancasila (Jakarta: Mizan, 2014), hal. 71.

${ }^{13}$ Jusuf Kalla, "NIIS dan Janji Surga." ideologi perlawanan menemukan momentumnya ketika terjadi instabilitas di berbagai bidang.

Alasan tersebut menjadi logis untuk menjelaskan mengapa gerakan semacam ISIS banyak berkembang di negara-negara yang dilanda konflik atau negara gagal. ISIS diibaratkan sebagai virus yang berkembang biak dalam tubuh negara karena kerusakan dan kelemahan sektor ekonomi, politik, dan militer, baik disebabkan oleh faktor eksternal maupun internal. ${ }^{14}$ Lebih dari itu, secara historis, Irak dan Suriah adalah dua wilayah yang memiliki nilai sejarah bagi peradaban Islam. Suriah (dahulu Syam) pernah menjadi pusat perdagangan di masa awal perkembangan Islam dan Baghdad (Irak) pernah menjadi pusat perkembangan kebudayaan Islam. $^{15}$ Oleh karena itu, kemunculan ISIS didasari keinginan mengembalikan kejayaan Islam di masa lalu melalui pendirian Negara Islam di dua wilayah tersebut.

Terlepas dari itu, cikal-bakal ISIS sendiri dapat ditelusuri dari berdirinya Jamaat al-Tawhid wa-l-Jihad (JTWJ) pada

${ }^{14}$ Ibid. Lihat juga Trias Kuncahyono, "Genesis ISIS dan 'Demonstrative Effect' di Indonesia," dalam Komaruddin Hidayat (ed.), Kontroversi Khilafah, hal. 231; Azyumardi Azra, "Khilafah dan Indonesia: Relevansi dan Reperkusi," dalam ibid,. hal. 234-235.

15 Jusuf Kalla, "Pemikiran Moderat Cegah Ideologi Ekstrim," [online] http://wapresri.go.id/index/preview/berita/25076 (diakses pada 30/04/2015). Pidato Wakil Presiden dalam International Conference Terrorism \& ISIS: Indonesia's Challenges Terrorism and ISIS, 23 Maret 2015. 
1999 di bawah pimpinan Abu Mus'ab alZarqawi. ${ }^{16}$ Sejak didirikan, JTWJ berjuang di Afghanistan, Chechnya, Bosnia, dan Kashmir, lalu kembali ke Irak melakukan perlawanan terhadap invasi AS pada tahun 2003. ${ }^{17}$ Pada tahun 2004, JTWJ kemudian bergabung dengan al-Qaida dan berubah menjadi al-Qaida Organization in the Land of the Two Rivers (Tanzim Qaidat al-Jihad fi Bilad al-Rafidayn) atau al-Qaida in Iraq (AQI). Zarqawi meyakini bahwa dengan berasosiasi dengan al-Qaida akan lebih mampu merekrut pasukan untuk berjihad dan memperoleh pendanaan. Sementara pada saat yang sama, al-Qaida sendiri membutuhkan pasukan untuk melakukan jihad di Irak yang dipandang sebagai front jihad melawan AS. ${ }^{18}$

AQI di bawah pimpinan Zarqawi kemudian menggandeng kelompok lain yang berafiliasi dengan al-Qaida dan membentuk Majlis Shura al-Mujahedin (MSM) pada 2006. ${ }^{19}$ Terbentuknya MSM

16 Al-Zarqawi disebut-sebut sebagai "kakekmoyang" berdirinya ISIS. Cikal bakal JTJW yang kemudian menjadi ISIS dapat dilacak jauh sampai pada awal tahun 1990-an yang dimulai di Yordania. Lebih lanjut lihat Trias Kuncahyono, "Genesis ISIS," hal. 208.

${ }^{17}$ Can Acun, "Neo al-Qaida: The Islamic State of Iraq and the Sham (ISIS)," SETA Foreign Policy Research Assistant, No. 10 June 2014, hal. 2.

18 Richard Barret, "The Islamic State," The Soufan Group, November 2014 (New York, TSG, 2014), hal. 11. Baca juga Trias Kuncahyono, "Genesis ISIS", hal. 214.

${ }_{19}$ Ada lima kelompok yang bersatu yakni Jaish at-Taifha al-Mansoura, Katbiyan Ansar al- diharapkan mampu menyatukan kelompokkelompok perlawanan Sunni yang ada di Irak. Namun, serangan AS pada 7 Juni 2006 menewaskan Zarqawi dan selanjutnya kepemimpinan AQI digantikan oleh Abu Hamza al-Muhajir. MSM di bawah kepemimpinan Muhajir mampu menyatukan kelompok-kelompok lain, seperti Soldiers of the Prophet's Companions (Jund al Sahaba), the Army of Conquerors (Jaish al Fatiheen) dan the Army of the Victorious Sect (Jaish al Taif al Mansura $).{ }^{20} \quad$ Pada perkembangan berikutnya, Muhajir mendeklarasikan berdirinya Islamic State of Iraq (ISI) pada Oktober 2006 dengan Abu Umar al-Quraisy al-Husaini al-Baghdadi sebagai pemimpin dan Muhajir sebagai Minister of War. Pada masa tersebut, ISI tetap menjadi afiliasi dari al-Qaida.

Perkembangan selanjutnya, Muhajir dan Abu Umar tewas pada tahun 2010 sehingga kepemimpinan ISI diambil alih oleh Abu Bakar al-Baghdadi. ISI di bawah kepemimpinan al-Baghdadi kemudian terlibat dalam membantu perjuangan Sunni dalam perang saudara yang terjadi di Suriah. ISI di Suriah berusaha berafiliasi dengan Jabhat AnNusra (JN). JN merupakan cabang al-Qaida di Suriah dengan pimpinan Abu Muhammad al-Jaulani. Akan tetapi, karena

Tawhid wal Sunnah, Faksi Syarah al-Jihad, Brigade al-Ghuraba, dan al-Ahwal Brigade.

${ }^{20}$ Can Acun, "Neo al-Qaida," hal 2. 
perbedaan pandangan dan ideologi, misi dan tujuan, serta metode perjuangan (manhaj), al-Qaida kemudian tidak mengakui ISI sebagai bagian dari jaringannya. ${ }^{21}$ Pada Februari 2014, Ayman al-Zawahiri, pemimpin tertinggi al-Qaida setelah tewasnya Usama bin Laden, menolak afiliasi ISI dengan JN. ${ }^{22}$

Mengenai hal tersebut, menurut Zelin, sekalipun ISIS pada hakikatnya merupakan inkarnasi dari al-Qaida, namun hubungan di antara keduanya ditandai dengan ketidakpercayaan (distrust), kompetisi (open competition), dan permusuhan (hostility). ${ }^{23}$ Zelin bahkan menggambarkan ISIS dan al-Qaida sebagai dua kelompok yang sedang terlibat war for supremacy sebagai global jihadist movement. Keduanya saling berebut supremasi untuk mengklaim kelompoknya sebagai gerakan atau kelompok jihad global. Jenkins bahkan menyebut bahwa ISIS dan al-Qaida adalah dua saudara yang saling "membunuh" (brothers killing brothers) ${ }^{24}$

\footnotetext{
${ }^{21}$ Richard Barret, "The Islamic State," hal. 12.

${ }^{22}$ Pertentangan antara ISIS dan JN disebabkan karena ISIS terdiri dari entitas pejuang asing yang mencapai 80 persen, sementara JN terdiri dari penduduk pribumi Suriah. Selain itu, JN tidak mendukung Negara Islam di seluruh wilayah, tetapi hanya fokus kepada Suriah. Ibid.; lihat juga Trias Kuncahyono, "Genesis ISIS," hal. 220-221.

${ }^{23}$ Aaron Y. Zelin, "The War between ISIS and al-Qaeda for Supremacy of the Global Jihadist Movements," Research Notes, Number 20-June 2014 (The Washington Institute for Near East Policy, 2014); 1-11

24 Brian Michael Jenkins, "Brothers Killing Brothers.”
}

Selanjutnya, dengan adanya pertentangan tersebut, ISIS di bawah pimpinan al-Baghdadi mendeklarasikan berdirinya ISIS pada 9 April 2013 yang mencakup wilayah Irak dan Suriah. Setelah menguasai beberapa daerah di Irak dan Suriah, seperti Falujjah, Mosul, dan Raqqah, ISIS mendeklarasikan berdirinya Islamic State (IS) pada 29 Juni 2014. Wilayah yang berhasil direbut dan dikuasainya diklaim sebagai wilayah kekhilafahan baru Islam dan Abu Bakar alBaghdadi sebagai khalifah. Sebagai kekhilafahan Islam, ISIS (IS) mengklaim memiliki otoritas agama, politik, dan militer bagi seluruh umat Islam dunia dengan mengajak seluruh umat Islam untuk bergabung menyokong eksistensi khilafah Islam yang dideklarasikannya. ${ }^{25}$

\section{ISIS dan Revivalisme Islam di Indonesia}

Penyebaran ideologi ISIS tidak hanya di Timur Tengah, tetapi juga ke Asia Tenggara. Terlebih lagi, di kawasan Asia Tenggara terutama Indonesia dan Malaysia, paham-paham dari kelompok yang berusaha mengimplementasikan syariat Islam atau mendirikan Negara Islam telah hadir sejak lama. Dalam kaitannya dengan itu, Liow dalam tulisannya di Foreign Affairs berusaha menganalisis beberapa faktor mengapa ideologi ISIS memperoleh

25 Organization of Islamic Cooperation, "Islamic Response to the Islamic State of Iraq and the Levant," MISH Model United Nations 2015, hal. 10 . 
simpati masyarakat Muslim Asia Tenggara, khususnya di Indonesia dan Malaysia. ${ }^{26}$

Faktor pertama adalah adanya pandangan teologis dan keimanan yang sama dengan kelompok ISIS. Sebagian umat Muslim melihat adanya hubungan paralel antara misi ISIS dengan "ramalan" dalam Islam bahwa pada akhirnya akan berdiri Khilafah ala Minhaj Nubuwwah atau kekhilafahan Islam seiring dengan runtuhnya pemerintahan otoriter di Jazirah Arab. Kedua, ISIS menyerukan sektarianisme melawan Syiah, di mana kondisi Asia Tenggara dinilai mendukung politik sektarianisme tersebut. Hal itu terlihat atas pelarangan Syiah di Malaysia sementara keberadaannya tidak diakui di Indonesia. Ketiga, adanya rasa simpati dan perasaan senasib sebagai umat Islam terhadap masyarakat Suriah kemudian mendorong masyarakat Muslim Asia Tenggara berangkat melakukan jihad atas nama misi kemanusiaan dan "panggilan suci agama."

Hadirnya paham untuk mendirikan Negara Islam sejatinya bukanlah sesuatu yang baru di Indonesia. ${ }^{27}$ Menurut juru

\footnotetext{
${ }^{26}$ Joseph Chinyong Liow, "ISIS Goes to Asia: Extremism in the Middle East Isn't Only Spreading West." Foreign Affairs, 21 September 2014, [online] http://www.foreignaffairs.com/articles/142004/j oseph-chinyong-liow/isis-goes-to-asia (diakses pada 04/10/2014).

${ }^{27}$ Lihat Azyumardi Azra, "Islam in Southeast Asia: Tolerant and Radicalism," makalah dipresentasikan pada Miegunyah Public Lecture, The University of Melbourne, 6 April 2005. Dalam Pradana Boy ZTF, Fikih Jalan
}

bicara Badan Nasional Penanggulangan Terorisme (BNPT) Irfan Idris, paham seperti ISIS merupakan paham yang telah berkembang lama di Indonesia. Hanya saja, ISIS adalah sebutan baru dari perkembangan paham tersebut, tetapi secara ideologi cenderung sama. ${ }^{28}$ Hal yang sama dikemukakan mantan Kepala BNPT Ansyaad Mbai, yang menyebut bahwa gerakan ISIS bukanlah "barang baru" di Indonesia. ISIS hanya nama baru dengan formasi orang-orang lama. Menurutnya, gerakan untuk mendirikan Negara Islam di Indonesia sudah ada sejak kelahiran Indonesia, awalnya bernama Negara Islam Indonesia (NII). ${ }^{29}$

Munculnya ide mendirikan NII dapat ditelusuri dari gerakan Darul Islam (DI) pimpinan Sekarmadji Maridjan Kartosoewirjo, yang muncul di Indonesia pada tahun 1940-an. Awalnya DI merupakan organisasi politik yang memiliki sayap militer dan ikut berjuang bersamasama Angkatan Bersenjata Republik

Tengah: Dialektika Hukum Islam dan MasalahMasalah Masyarakat Modern (Jakarta: Hamdalah, 2008), hal. 154.

28 Dani Prabowo, "BNPT: ISIS Berlindung di Balik Simbol Langit, Padahal Radikal," Kompas, 19 Maret 2015, [online] http://nasional.kompas.com/read/2015/03/19/15 273091/BNPT.ISIS.Berlindung.di.Balik.Simbol. Langit.Padahal.Radikal (diakses pada 13/04/2015).

29 Fabian Januarius Kuwado, "ISIS Bukan Barang Baru di Indonesia...," Kompas, 31 Maret 2015, [online] http://nasional.kompas.com/read/2015/03/31/19 311411/.ISIS.Bukan.Barang.Baru.di.Indonesia. (diakses pada 13/04/2015). Baca juga Komaruddin Hidayat (ed.), Kontroversi Khilafah, hal. 148. 
Indonesia (ABRI, sekarang Tentara Nasional Indonesia/TNI) melawan penjajah Belanda. $^{30}$ Namun kemudian, setelah Indonesia memiliki kedaulatan penuh pada 1949, DI masih tetap mempertahankan tentara dan perjuangannya untuk mendirikan NII. Menurut Wahid, DI berusaha mengubah negara bangsa menjadi negara agama. Mengganti ideologi negara Pancasila dengan Islam versi mereka atau bahkan menghilangkan NKRI dan menggantinya dengan Khilafah Islamiyah. ${ }^{31}$

Dalam perjalanannya, gerakan DI melahirkan beberapa kelompok. Salah satunya adalah Jamaah Islamiyah (JI) pimpinan Abdullah Sungkar dan Abu Bakar Ba'asyir. Keduanya kemudian melakukan pelarian ke Malaysia untuk menghindari penangkapan yang dilakukan rezim Orde Baru dan mengembangkan JI di sana. JI merupakan organisasi ideologis atau gerakan yang bermaksud membangun Khilafah Islamiyah di regional Asia Tenggara. Tujuan jangka panjang JI adalah mendirikan Daulah Islamiyah atau Negara Islam di kawasan Asia Tenggara, termasuk dengan cara kekerasan. ${ }^{32}$ Pusat Daulah Islamiyah adalah Indonesia dengan wilayah Malaysia, Filipina, Singapura dan Brunei.

\footnotetext{
30 Luqman Hakim, Terorisme Indonesia (Surakarta: FSIS, 2004), hal. 48

31 Abdurrahman Wahid, "Musuh dalam Selimut," dalam Abdurrahman Wahid (ed.), Ilusi Negara Islam: Ekspansi Gerakan Islam Transnasional di Indonesia (Jakarta: LibForAll Foundation, 2009), hal. 18.

${ }^{32}$ Luqman Hakim, Terorisme Indonesia, hal. 49.
}

Menjelang dan setelah tumbangnya Orde Baru pada tahun 1998 kemudian memperlebar ruang gerak bagi eksistensi gerakan dan paham-paham yang memiliki cita-cita mendirikan Negara Islam. ${ }^{33}$ Era Reformasi pasca Orde Baru menimbulkan perubahan-perubahan substansial dengan hadirnya era kebebasan publik (demokrasi) dan menjadikan isu kembalinya khilafah menemukan momentumnya. ${ }^{34}$ Berakhirnya rezim Orde Baru, menurut Boy, sering kali dianggap sebagai titik di mana kelompokkelompok Islam muncul kembali dalam sejarah Indonesia kontemporer. ${ }^{35}$ Salah satu konsekuensinya adalah semakin tumbuhnya identitas komunal dan identitas primordial. Hal itu ditandai dengan munculnya partaipartai dan organisasi-organisasi massa baru yang mengusung simbol-simbol primordial, semisal agama. Hal itu pula yang menjadi daya pendorong (impetus) bagi eksistensi gerakan-gerakan Islam dengan cita-cita Khilafah Islamiyah. ${ }^{36}$ Fenomena tersebut antara lain dapat dilihat dari eksistensi Hizbut Tahrir Indonesia (HTI), Laskar Jihad (yang kemudian membentuk Forum Komunikasi

Ahlus-Sunnah

\footnotetext{
${ }^{33}$ Lihat Abdurrahman Wahid (ed.), Ilusi Negara Islam, hal. 96.

34 Komaruddin Hidayat (ed.), Kontroversi Khilafah, hal. 148; Ridwan Al-Makassary, Terorisme Berjubah Agama (Jakarta: Pusat Bahasa dan Budaya UIN Syarif Hidayatullah Jakarta dan Konrad Adenauer Stiftung, 2003), hal. 19.

${ }^{35}$ Pradana Boy ZTF, Fikih Jalan Tengah, hal. 154.

${ }^{36}$ Ridwan Al-Makassary, Terorisme Berjubah, hal. 20.
} 
Waljama'ah/FKAWJ), Laskar Jundullah, Laskar Fisabilillah, Front Pembela Islam (FPI), Komite Persiapan Penerapan Syariah Islam (KPPSI), dan lainnya, ${ }^{37}$ selain JI yang telah hadir di era 1990-an (yang kemudian berubah nama menjadi Majelis Mujahidin Indonesia/MMI, lalu berganti lagi menjadi Jamaah Ansharut Tauhid/JAT). Kelompokkelompok tersebut terlibat dalam apa yang disebut sebagai upaya Islamisasi masyarakat dari sistem sekuler dan berupaya menegakkan nilai-nilai Islam. Kenyataan ini, oleh Jainuri dan Boy, dipandang membuktikan tesis William R. Liddle bahwa saat sistem politik pasca Orde Baru berubah di mana Islam skriptualis menemukan momentum metamorfosis kebangkitannya. ${ }^{38}$

Pada umumnya, meskipun tidak semua, aspirasi kelompok-kelompok yang disebut di atas dipengaruhi oleh gerakan Islam transnasional, ${ }^{39}$ antara lain yang berpaham Wahabi/Salafi, Ikhwanul

37 Abdurrahman Wahid (ed.), Ilusi Negara Islam, hal. 96, Pradana Boy ZTF, Fikih Jalan Tengah, hal. 154.

${ }^{38}$ William R. Liddle, "Scriptualism: One Form of Islamic Political Thought and Action in New Order Indonesia," dalam Mark R. Woodward (ed.), Toward a New Paradigm: Recent Development in Indonesian Islamic Thought (Arizona: Arizona State University, 1996), hal. 326-356. Lihat dalam Achmad Jainuri, et al., Terorisme dan Fundamentalisme Agama: Sebuah Tafsir Sosial (Malang: Bayumedia Publishing bekerja sama Pusat Studi Islam dan Filsafat UMM, 2003), hal. 216; lihat juga dalam Pradana Boy ZTF, Fikih Jalan Tengah, hal. 77.

${ }^{39}$ Lihat Pradana Boy ZTF, Fikih Jalan Tengah, hal. 169.
Muslimin (IM), atau gabungan keduanya, serta Hizbut Tahrir (HT). ${ }^{40}$ Melalui jargonjargon seperti membela Islam, penerapan syariah, maupun penegakan Khilafah Islamiyah, gerakan-gerakan tersebut berusaha merebut simpati. Bagi umat Islam yang belum memiliki pemahaman yang mendalam tentang ajaran agama, ungkapanungkapan tersebut bisa jadi ampuh untuk menarik simpati mereka. ${ }^{41}$ Jargon dan ungkapan yang sama setidaknya juga

40 Namun, perlu ditegaskan di sini, bahwa kendatipun IM, HT, dan Wahabi cenderung memiliki "cita-cita" yang sama yakni perlunya penegakan syariat Islam, namun secara organisasional dan beberapa pihak di dalamnya tidak mendukung perjuangan ISIS. HT Indonesia misalnya menolak konsep Negara Islam dan sistem khilafah dari ISIS karena menurutnya khilafah yang sesuai dengan tuntutan Nabi Muhammad SAW, yakni bukanlah dengan cara mengangkat senjata dan menebar kebencian terhadap manusia dan institusi negara, melainkan dengan cara dakwah. Sementara ulama terkemuka IM, Yusuf Qardhawi, mengatakan bahwa deklarasi khilafah oleh ISIS tidak sah secara syariah Islam dan tidak membantu proyek kejayaan Islam. Adapun DDII, sebagai organisasi di Indonesia yang disebut berafiliasi dengan Wahabi, juga menolak ISIS.

Lihat Linda Trianita "Hizbut Tahrir Indonesia Bantah Dukung ISIS," Tempo, 23 Maret 2015 [online]

http://nasional.tempo.co/read/news/2015/03/23/ 078652087/Hizbut-Tahrir-Indonesia-Bantah-

Dukung-ISIS (diakses pada 22/05/2015); "Hizbut Tahrir Indonesia: Kami Menolak Keberadaan ISIS," 27 Maret 2015 [online] http://hizbut-tahrir.or.id/2015/03/27/hizbuttahrir-indonesia-kami-menolak-keberadaan-isis/ (diakses pada 22/05/2015); Nurmulia Rekso Purnomo, "MUI Serukan Agar Umat Islam Tolak ISIS," Tribun News, 7 Agustus 2014 [online]

http://www.tribunnews.com/nasional/2014/08/0 7/mui-serukan-agar-umat-islam-tolak-isis (diakses pada 22/05/2015).

${ }^{41}$ Abdurrahman Wahid (ed.), Ilusi Negara Islam, hal. 90. 
digaungkan oleh ISIS. Sasarannya adalah merebut simpati umat Islam melalui propaganda jihad. Tidak hanya masyarakat yang belum memiliki pemahaman yang mendalam tentang Islam, faktanya ISIS juga merebut simpati dari simpatisan kelompok-kelompok dan gerakan Islam.

Menurut mantan Wakil Kepala Badan Intelijen Negara (BIN) As'ad Said Ali, ISIS telah memiliki jaringan di Indonesia. Jaringan tersebut bernama Jamaah Ansarul Daulat (JAD) yang merupakan gabungan dari sejumlah kelompok dan gerakan revivalisme Islam yang sebelumnya telah ada di Indonesia. JAD terdiri dari beberapa faksi, seperti Jamaah Ansharul Tauhid (JAT), Jamaah Ansharul Khilafah (JAK), Mujahidin Indonesia Timur (MIT), dan Mujahidin Indonesia Barat (MIB), serta kelompok AlMuhajirun yang merupakan sempalan dari kelompok HT. ${ }^{42}$ Lebih lanjut, titik beranjak dari respons pemerintah Indonesia terhadap isu dan ancaman ISIS di Indonesia salah satunya dimulai dari munculnya video di Youtube berjudul Join the Ranks. Orang yang tampil di video itu adalah Abu Muhammad Al-Indonesi yang menyitir beberapa ayat untuk mengajak umat Islam Indonesia melakukan jihad ke Irak dan

${ }^{42}$ Dani Prabowo, "Mantan Wakil Kepala BIN Sebut ISIS Punya Jaringan Baru di Indonesia," Kompas, 22 Maret 2015, [online] http://nasional.kompas.com/read/2015/03/22/14 022091/Mantan.Wakil.Kepala.BIN.Sebut.ISIS.P unya.Jaringan.Baru.di.Indonesia (diakses pada 13/04/2015).
Suriah. Munculnya video itu kemudian direspons pemerintah Indonesia dengan menyatakan bahwa paham ISIS dilarang di Indonesia. Abu Muhammad atau Bahrum Syah merupakan jaringan organisasi AlMuhajirun. $^{43}$ Al-Muhajirun berusaha membentuk jaringan global dengan mengadvokasi kelompok-kelompok yang mendukung penegakan syariat Islam, bahkan dengan cara radikal. Cabang pertamanya berbasis di Inggris, yang kemudian disebut "Islam4UK" atau "Sharia4UK". Cabangnya di setiap negara kemudian menggunakan "Sharia4", di Indonesia menjadi "Sharia4Indonesia" yang berdiri sejak 2010. Kelompok atau gerakan revivalisme Islam tertentu yang diinspirasi oleh Al-Muhajirun itulah kemudian pertama kali menjadi jaringan dari pro-ISIS di Indonesia. ${ }^{44}$ Kelompok-kelompok tersebut antara lain Tauhid wal Jamaah (TJW) yang dipimpin Aman Abdurrahman, Forum Aktivis Syariat Islam (FAKSI) pimpinan M. Fachry, ${ }^{45}$ MIT yang dipimpin Santoso, MIB, serta JAT pimpinan Abu Bakar Ba'asyir. Kelompok-kelompok inilah yang disebut pertama kali menyatakan

\footnotetext{
${ }^{43}$ Baca Institute for Policy Analysis of Conflict, "The Evolution of ISIS in Indonesia," IPAC Report No. 13, 24 September 2014, hal 1. ${ }^{44}$ Ibid.

${ }^{45}$ Fachry membuat situs web yang disebut AlMustaqbal (www.almustaqbal.net) untuk mengkampanyekan Shariah4Indonesia yang selanjutnya menjadi media propaganda penyebaran paham ISIS, juga menerbitkan majalah dengan nama yang sama. Lihat ibid, hal. 7 .
} 
dukungannya pada ISIS, terutama setelah berubah menjadi IS pada 29 Juni $2014 .{ }^{46}$

Penyebaran ideologi ISIS dimulai dengan dukungan Abu Bakar Ba'asyir dan Aman Abdurrahman terhadap ISIS yang selanjutnya diikuti oleh para pengikutnya. Ba'asyir, menurut narasumber, bahkan menyatakan bahwa jika tidak bisa ikut berjihad mendukung ISIS, setidaknya bergabung dengan MIT atau MIB, sebab keduanya memiliki ideologi yang sama. ${ }^{47}$ Dukungan Ba'asyir terhadap ISIS kemudian mengakibatkan perpecahan di tubuh JAT. Setelah Ba'asyir menyatakan dukungannya terhadap ISIS, seorang tokoh teras JAT bernama Muhammad Achwan berbeda sikap. Ia memutuskan tidak berbaiat kepada ISIS seperti yang dilakukan Ba'asyir bersama 23 narapidana terorisme pengikutnya di Lapas Nusakambangan.

Akibatnya, Ba'asyir meminta Achwan keluar dari barisan JAT dan membentuk kelompok dakwah terpisah hingga terbentuklah Jamaah Ansharul Syariah (JAS). Meskipun begitu, Achwan tetap meyakini bahwa berdirinya khilafah adalah bagian dari kewajiban syariat. Mereka kemudian keluar dan membentuk kelompok Jamaah Ansharul Syariah $(\mathrm{JAS}){ }^{48}$ Pihak lain membentuk Jamaah

${ }^{46}$ Ibid.

${ }^{47}$ Ibid.

${ }^{48}$ Lihat Fajar Riza U1 Haq, "Islam Indonesia Abad ke-21: Kiblat Islam Dunia?," dalam Komaruddin Hidayat (ed.), Kontroversi Khilafah, hal. 167-168.
Ansharul Khilafah (JAK). Perbedaannya terletak pada dukungan dan baiat pada ISIS. Jika JAS menolak memberikan dukungan dan baiat kepada ISIS, maka JAK sebaliknya berbaiat mendukung ISIS. Namun, pada hakikatnya keduanya memiliki tujuan yang sama yakni penegakan syariat Islam menurut versi mereka masing-masing.

\section{Respons Pemerintah Indonesia}

Perkembangan jaringan dan simpatisan ISIS di Indonesia ditandai dengan beredarnya video di Youtube berjudul "Join the Ranks" pada 23 Juli $2014 .^{49}$ Video yang berisi seruan jihad untuk mendukung ISIS, yang kemudian diikuti dengan banyaknya simpatisan yang mendukung ISIS di berbagai daerah. ${ }^{50}$

49 Video berdurasi sekitar delapan menit tersebut diunggah ke Youtube pada 22 Juli 2014 dan telah diblokir oleh Kementerian Komunikasi dan Informatika. Berdasarkan penelusuran intelijen, orang yang tampil di video tersebut adalah Bahrumsyah atau menyebut dirinya sebagai Abu Muhammad alIndonesiy, seorang terduga teroris jaringan Mujahidin Indonesia Timur (MIT). Tia Mariatul Kibtia, "The Contemporary Islamic State of Indonesia: Threat and Challenges," Middle East Institute, 14 Januari 2015, [online] http://www.mei.edu/content/map/contemporaryislamic-state-indonesia-threats-and-challenges (diakses pada 11/02/2015); "Police to Track Down Indonesians on ISIL Video," The Jakarta Post, 7 Agustus 2015, [online] http://www.thejakartapost.com/news/2014/08/0 7/police-track-down-indonesians-isil-video.html (diakses pada 11/02/2015).

50 Beberapa daerah yang diisukan telah ditembus oleh jaringan ISIS antara lain Jakarta, Bogor, Bekasi, Surabaya, Ngawi, Solo, Malang, Makassar, Poso, serta Bima. Istiqomatul, "Kenapa Solo Disebut Basis Gerakan ISIS?" 
Sebagai respons, sejak 4 Agustus 2014 pemerintah Indonesia yang saat itu di bawah pemerintahan Presiden Susilo Bambang Yudhoyono (SBY) kemudian secara resmi melarang ISIS di Indonesia, baik secara formal maupun informal. Pemerintah memandang bahwa ideologi ISIS bertentangan dengan ideologi Pancasila dan kondisi keberagaman yang ada di Indonesia. ${ }^{51}$

\section{Pemerintah Indonesia kemudian} melakukan sejumlah langkah sebagai respons terhadap ISIS, di antaranya mencakup pencegahan WNI ke Suriah atau Irak, pemantauan yang ketat terhadap WNI yang diketahui berada di Suriah, mengetatkan pengelolaan terorisme di lembaga pemasyarakatan, ${ }^{52}$ serta pemantauan terhadap wilayah-wilayah yang dinilai rawan, dan juga melalui penegakan

\footnotetext{
Tетро, 8 Agustus 2014, [online] http://www.tempo.co/read/news/2014/08/08/078 598073/Kenapa-Solo-Disebut-Basis-GerakanISIS/1/0 (diakses pada 17/02/2015); "Kepala Daerah Wajib Cegah ISIS," Jawa Pos, 8 Agustus 2014, [online] http://www.jawapos.com/baca/artikel/5572/Kep ala-Daerah-Wajib-Cegah-ISIS- (diakses pada 17/02/2015).

51 Lihat Frances Martel, "Indonesia Criminalizes Support for ISIS," [online] http://www.breitbart.com/nationalsecurity/2014/08/06/indonesia-criminalizessupport-for-isis/ (diakses pada 11/2/2015).

${ }^{52}$ Ditandai dengan dikeluarkannya Surat Edaran No. Pas-330.PK.01.04.03 tahun 2014 tentang Peningkatan Kewaspadaan Terkait Aktivitas Narapidana Teroris di Lembaga Pemasyarakatan dan dan Rumah Tahanan pada 5 August 2014 oleh Menteri Hukum dan Hak Asasi Manusia.
}

hukum. ${ }^{53}$ Selain itu, Menteri Dalam Negeri (Mendagri) kemudian mengeluarkan surat edaran. Surat Edaran yang bernomor 450/3806/SJ per tanggal 7 Agustus 2014 itu ditujukan kepada gubernur, bupati, dan walikota di seluruh daerah dan juga ditembuskan kepada Kepala Bakesbangpol provinsi dan kabupaten/kota di Indonesia. ${ }^{54}$ Lebih lanjut, setelah transisi ke pemerintahan Joko Widodo, presiden Joko Widodo menyatakan bahwa Indonesia memiliki pendekatan keagamaan (religion approach) dan pendekatan budaya (cultural approach) dalam menyikapi ISIS. Indonesia menolak ajakan masyarakat internasional untuk memerangi ISIS dengan cara kekerasan menggunakan pendekatan keamanan (security approach).

Joko Widodo mengaku menolak ajakan Sekretaris Jenderal PBB Ban KiMoon untuk ikut bersama-sama memerangi ISIS secara militer. Karena, menurutnya, Indonesia perlu mengedepankan pendekatan lain yang non-militeristik. Hal yang sama diyakini Susilo Bambang Yudhoyono (sebelum digantikan oleh Joko Widodo) dalam wawancaranya dengan The Australian mengatakan bahwa untuk jangka

53 Lihat Sabrina Asril, "Ini Tujuh Instruksi Presiden Untuk Pencegahan Paham ISIS," Kompas, 14 September 2014, [online] http://nasional.kompas.com/read/2014/09/14/23 185721/Ini.Tujuh.Instruksi.Presiden.untuk.Penc egahan.Paham.ISIS (diakses pada 14/02/2015).

54 Lihat Surat Edaran Menteri Dalam Negeri Republik Indonesia Nomor 450/3806/SJ Tanggal 7 Agustus 2014 perihal Peran Akif Kepala Daerah dalam Penanganan Penyebaran Paham dan Ideologi ISIS di Indonesia. 
panjang tindakan militer saja tidak cukup untuk menghadapi ancaman ISIS. Menurutnya, masyarakat internasional memerlukan langkah-langkah politik dan lainnya untuk mengatasi akar penyebab konflik untuk dapat menghentikan siklus kekerasan dan ekstremisme. ${ }^{55}$

\section{Kesimpulan}

ISIS merupakan gerakan transnasional di mana ideologinya telah menyebar ke berbagai negara, termasuk Indonesia. Awalnya, ISIS adalah gerakan lokal di Irak yang terbentuk sebagai respons terhadap invasi AS yang melengserkan kekuasaan Saddam Husain. Selanjutnya, berkembang dan meluas ke Suriah seiring pergolakan negara-negara Arab selama Arab Spring.

Setelah mencapai eksistensinya di Suriah, ISIS meneguhkan berdirinya kekhalifahan Islam di Irak dan Suriah. Guna memperoleh dukungan atas cita-cita tersebut, ISIS menyebarkan propaganda via media sosial yang selanjutnya menarik simpati umat Islam di banyak negara, termasuk Indonesia. Dalam konteks

55 Baca Halimatus Sa'diyah, "Jokowi Tolak Perangi ISIS dengan Cara Kekerasan," Republika, 13 November 2014, [online] http://www.republika.co.id/berita/internasional/ global/14/11/13/nez6ke-jokowi-tolak-perangiisis-dengan-cara-kekerasan (diakses pada 14/02/2015); Novy Lumanaw, "SBY: ISIS Terapkan Ideologi Eksklusif Antidemokrasi," [online] http://www.beritasatu.com/nasional/216413sby-isis-terapkan-ideologi-eksklusifantidemokrasi.html (diakses pada 14/02/2015).
Indonesia, cita-cita dan ideologi ISIS untuk mendirikan Negara Islam memperoleh simpati seiring telah hadirnya gerakangerakan revivalisme Islam di Indonesia sejak beberapa dekade. Persentuhannya dengan kelompok/gerakan revivalisme Islam di Indonesia menjadikan ISIS dapat dengan mudah menyebar dan memperoleh simpati di berbagai daerah. 


\section{Daftar Pustaka}

\section{Buku}

Al-Makassary, Ridwan. Terorisme Berjubah Agama. Jakarta: Pusat Bahasa dan Budaya UIN Syarif Hidayatullah Jakarta dan Konrad Adenauer Stiftung, 2003.

Arif, Syaiful. Deradikalisasi Islam: Paradigma dan Strategi Islam Kultural. Depok: Penerbit Koekoesan, 2010.

Chandler, Michael, dan Rohan Gunaratna. Countering Terrorism: Can We Meet the Threat of Global Violence? London: Reaktion Books, 2007.

Hakim, Lukman. Terorisme Indonesia. Surakarta: Forum Studi Islam Surakarta, 2004.

Hidayat, Komaruddin (ed.). Kontroversi Khilafah: Islam, Negara, dan Pancasila. Jakarta: Mizan, 2014.

Huntington, Samuel P. Benturan Antar Peradaban dan Masa Depan Politik Dunia. Cetakan Kedelapan. Yogyakarta: Penerbit Qalam, 2004.

Wahid, Abdurrahman (ed.). Ilusi Negara Islam: Ekspansi Gerakan Islam Transnasional di Indonesia. Jakarta: LibForAll Foundation, 2009.

ZTF, Pradana Boy, Fikih Jalan Tengah: Dialektika Hukum Islam dan MasalahMasalah Masyarakat Modern. Jakarta: Hamdalah, 2008.

\section{Artikel Jurnal dan Laporan Penelitian}

Acun, Can. "Neo al-Qaida: The Islamic State of Iraq and the Sham (ISIS)," SETA Foreign Policy Research Assistant, No. 10 June 2014.

Barret, Richard. "Foreign Fighters in Syria," The Soufan Group, June 2014. New York: TSG, 2014.

Barret, Richard. "The Islamic State," The Soufan Group, November 2014. New York: TSG, 2014.

Institute of Policy Analysis of Conflict. "The Evolution of ISIS in Indonesia," IPAC Report No. 13, 24 September 2014.

Institute of Policy Analysis of Conflict. "Support for 'Islamic State' In
Indonesia Prisons," IPAC Report No. 15, 19 January 2015.

Jenkins, Brian Michael. "Brothers Killing Brothers." Perspective RAND Corporation, 2014; 2-13.

Organization of Islamic Cooperation. "Islamic Response to the Islamic State of Iraq and the Levant," MISH Model United Nations 2015.

Seal L. Yom, "Islam and Globalization: Secularism, Religion, and Radicalism," International Politics and Society 4/2002.

Zelin, Aaron Y. "The War between ISIS and al-Qaeda for Supremacy of the Global Jihadist Movements," Research Notes, Number 20-June 2014. The Washington Institute for Near East Policy, 2014.

\section{Artikel Online}

Berger, J. M. "How ISIS Games Twitter," [online]

http://www.theatlantic.com/internation al/archive/2014/06/isis-iraq-twittersocial-media-strategy/372856/ (diakses pada 04/10/2014).

Chengu, Garikai. "War on Terror is Terrorism: How the US Helped Create Al Qaeda and ISIS," Counter Punch, Weekend Edition September 19-21, 2014, [online] http://www.counterpunch.org/2014/09/ 19/how-the-us-helped-create-al-qaedaand-isis/ (diakses pada 06/03/2015).

Cron, Aidan. "ISIS: Born in the US," [online]

http://ehschronicle.com/2015/02/isisborn-in-the-usa/ (diakses pada 06/03/2015).

Istiqomatul. "Kenapa Solo Disebut Basis Gerakan ISIS?" Tempo, 8 Agustus 2014, [online] http://www.tempo.co/read/news/2014/ 08/08/078598073/Kenapa-SoloDisebut-Basis-Gerakan-ISIS/1/0 (diakses pada 17/02/2015).

Kibtia, Tia Mariatul. "The Contemporary Islamic State of Indonesia: Threat and Challenges," Middle East Institute, 14 Januari 2015, [online] http://www.mei.edu/content/map/conte mporary-islamic-state-indonesia- 
threats-and-challenges (diakses pada 11/02/2015).

Kuwado, Fabian Januarius. "ISIS Bukan Barang Baru di Indonesia...," Kompas, 31 Maret 2015, [online] http://nasional.kompas.com/read/2015/ 03/31/19311411/.ISIS.Bukan.Barang.

Baru.di.Indonesia. (diakses pada 13/04/2015).

Liow, Joseph Chinyong. "ISIS Goes to Asia: Extremism in the Middle East Isn't Only Spreading West." Foreign Affairs, 21 September 2014, [online] http://www.foreignaffairs.com/articles/ 142004/joseph-chinyong-liow/isis-

goes-to-asia (diakses pada 04/10/2014).

Prabowo, Dani. "BNPT: ISIS Berlindung di Balik Simbol Langit, Padahal Radikal," Kompas, 19 Maret 2015, [online]

http://nasional.kompas.com/read/2015/ 03/19/15273091/BNPT.ISIS.Berlindun g.di.Balik.Simbol.Langit.Padahal.Radi kal (diakses pada 13/04/2015).

Purnomo, Nurmulia Rekso. "MUI Serukan Agar Umat Islam Tolak ISIS," Tribun News, 7 Agustus 2014, [online] http://www.tribunnews.com/nasion al/2014/08/07/mui-serukan-agarumat-islam-tolak-isis (diakses pada 22/05/2015).

Trianita, Linda. "Hizbut Tahrir Indonesia Bantah Dukung ISIS," Tempo, 23 Maret 2015, [online] http://nasional.tempo.co/read/news/ 2015/03/23/078652087/Hizbut-

Tahrir-Indonesia-Bantah-DukungISIS (diakses pada 22/05/2015).

Weber, Peter. "America Created the Islamic State of Iraq and Syria? Meet the ISIS "Truthers'," The Week, 2 September 2014, [online] http://theweek.com/articles/444103/ america-created-islamic-state-iraqsyria-meet-isis-truthers (diakses pada 18/03/2015).

\section{Surat Kabar}

Kalla, Jusuf. "NIIS dan Janji Surga," Kompas, 24 April 2015. 